\title{
IMPLEMENTASI UNDANG-UNDANG DESA NO. 6 TAHUN 2014 TENTANG PENYETARAAN GENDER DAN PERANAN PEREMPUAN DALAM PEMBANGUNAN DESA
}

\author{
Rahmawati \\ Sekolah Tinggi Ilmu Administrasi (STIA) Satya Negara Palembang \\ Email : rwati6676@gmail.com
}

\begin{abstract}
This study discusses the Implementation of Village Law No. 6 of 2014 concerning Gender Equality and the Role of Women in Village Development. The purpose of this study is to find out how the Village Law No. 6 of 2014 provides opportunities and opportunities for women in the village to play a role in village development. So that there is gender equality between village ranks which is usually dominated by men, women can also be given roles to sit as members of village officials. Gender roles are the roles played by women and men in accordance with the environmental status, culture and structure of society. This role is taught to every member of society, community and certain social groups that are prepared as roles of women and men. A good method of village development must involve all members of the community and involve activities directly related to their socio-economic interests. As a process, village development is a process of cultural transformation that begins with traditional life that relies on hereditary habits to be transformed into a modern society that bases life progress on a willingness to accept science and technology. The research method used is descriptive qualitative method, namely by gathering various information obtained in the form of written or oral words from people or observable behavior. Research results from the Implementation of the Village Law No. 6 of 2014 concerning Gender Equality and the Role of Women in Village Development is that women in village development have rights and equality with men. So what is expected is that gender equality for women in the village in participating in village development can be done well by providing space and opportunities for women to contribute to village development.
\end{abstract}

Keywords: Equalization of women, the role of women, rural development

\section{PENDAHULUAN}

Negara akan dipandang mulia bila dianggap sukses mengelola potensi perempuan. Apalagi populasi perempuan di negara itu hampir separuh dari jumlah laki-laki. Karena itu, potensi perempuan harus dikelola dengan baik dengan memberdayakan perempuan disegala bidang pembangunan. Para pendiri negeri ini, sungguh sangat arif dalam menyusun UUD 1945 menghargai peranan wanita pada masa silam dan mengantisipasi pada masa yang akan datang, dengan tidak ada satu kata pun yang bersifat diskriminatif terhadap wanita. Konstitusi ini dengan tegas menyatakan persamaan hak dan kewajiban bagi setiap warga negara (baik pria maupun wanita).

Di dalam GBHN 1993 di antaranya juga diamanatkan, bahwa perempuan mempunyai hak dan kewajiban yang sama dengan pria dalam pembangunan. Selain itu, pengambil keputusan 
juga telah meratifikasi (mengesahkan) konvensi penghapusan segala bentuk diskriminasi terhadap wanita dalam UU No. 7Tahun 1984.

Namun, kenyataan menunjukkan bahwa wanita mengalami ketertinggalan atau ketidakberuntungan lebih banyak dibandingkan dengan pria di antaranya di bidang pendidikan, kesehatan, ketenagakerjaan, penguasaan dan pemanfaatan ilmu pengetahuan dan teknologi. Oleh karena itu, peningkatan peranan wanita dalam pembangunan yang berwawasan gender sebagai bagian integral dari pembangunan nasional, mempunyai arti penting dalam upaya untuk mewujudkan kemitrasejajaran yang harmonis antara pria dengan wanita atau mewujudkan kesetaraan dan keadilan gender dalam berbagai bidang kehidupan dan pembangunan.

Sejak sepuluh tahun belakangan ini, kata gender telah memasuki perbendaharaan disetiap diskusi dan tulisan sekitar perubahan sosial dan pembangunan dunia ketiga. Demikian juga di Indonesia, hampir semua uraian tentang program pemberdayaan masyarakat maupun pembangunan di kalangan organisasi non-pemerintah diperbincangkan masalah gender. Istilah gender digunakan untuk menjelaskan antara laki-laki dan perempuan. Misalnya bahwa perempuan itu lemah lembut, cantik, emosional atau keibuan. Sementara laki-laki dianggap sebagai orang yag kuat, rasional, jantan, perkasa. Ciri dari sifat itu sendiri merupakan sifat-sifat yang dapat dipertukarkan. Semua hal yang dapat dipertukarkan antara sifat laki-laki dan perempuan, yang bisa berubah dari waktu ke waktu serta berbeda dari tempat yang satu ke tempat yang lainnya, maupun berbeda dari suatu kelas ke kelas yang lain, itulah yang kemudian dikenal sebagai konsep gender.Istilah ini tentu berbeda dengan istilah seks yang merupakan perbedaan jenis kelamin secara bologis yang tidak dapat dipertukarkan.

World Bank menyebutkan bahwa kesetaraan gender merupakan persoalan pokok pembangunan yang akan memperkuat kemampuan negara untuk berkembang, mengurangi kemiskinan danmemerintah secara efektif. Dalam konteks itulah jika negara kita mau membangun pemerintahan yang maju setidaknya memperhatikan masalah secara khusus yang berkaitan dengan kesetaraan gender (World Bank, 2001).

Peningkatan peranan wanita dalam pembangunan yang berwawasan gender sebagai bagian integral dari pembangunan nasional mempunyai arti penting dalam upaya untuk mewujudkan kemitraansejajaran yang harmonis antara pria dengan perempuan atau mewujudkan kesetaraan dan keadilan gender dalam berbagai bidang kehidupan dan pembangunan. Disebutkan dalam intruksi presiden No 9 tahun 2000 tentang penganusutamaan gender dalam pembangunan nasional, Presiden Republik Indonesia menimbang bahwa dalam rangka meningkatkan kedudukan, peran, dan kulitas perempuan, serta upaya mewujudkan kesetaraan dan keadilan gender dalam kehidupan kelurga, bermasyarakat, berbangsa, dan bemegara di pandang perlu melakukan strategi pengarusutamaan gender ke dalam seluruh proses pembangunann nasional.Kemitrasejajaran yang harmonis antara pria dengan perempuan adalah suatu kondisi 
hubungan kedudukan dan peranan yang dinamis antara pria dengan perempuan. Pria dan perempuan mempunyai persamaan kedudukan, hak, kewajiban dan kesempatan, baik dalam kehidupan berkeluarga, bermasyarakat, berbangsa dan bernegara maupun dalam kegiatan pembangunan di segala bidang.

Dalam hal persamaan kedudukan, baik pria maupun perempuan sama-sama berkedudukan sebagai subjek atau pelaku pembangunan. Dalam kedudukan sebagai subjek pembangunan, pria dan perempuan mempunyai peranan yang sama dalam merencanakan, melaksanakan, memantau dan menikmati hasil pembangunan. Gender sendiri di pahami sebagai sebuah konstruksi sosial tentang relasi laki-laki dan perempuan yang di konstruksikan oleh sistem dimana keduanya berada dalam kenyataan konstruksi sosial ini di konstruksikan oleh kekuasaan, baik kekuasaan politik, ekonomi, sosial kultural bahkan fisikal karena sebagimana halnya kenyataan kekuasaan adalah identik dengan kepemimpinan. (Nugroho. 2008,19)

Pemerintah melalui undang-undang nomor 6 tahun 2014 tentang desa memberikan kebebasan kepada desa dalam pengelolaan sistem pemerintahannya. Sebagaimana terdapat dalam pasal 34 UU nomor 6 tahun 2014 tentang kewenangan desa berdasarkan hak asal-usul sebagaimana dimaksud dalam pasal 33 hunuf a, paling sedikit terdiri atas system organisasi masyakat adat, pembinaan kelembagaan masyarakat, pembinaan lembaga dan hukum adat, pengelolaan tanah khas desa serta pengembanganperan masyarakat desa. Dalam hal pengembangan peran masyarakat desa kesataraan gender sangat dibutuhkan karenapembangunan tidak terlepas dari peran masyarakat suatu daerahuntuk ikut berkontribusi, sehingga sangat disayangkan jika tidak adanya kesetaraan gender. Disisi lain menurut pasal 68 mewajibkan masyarakat desa untuk ikutberpartisipasi dalam berbagai kegiatan desa dan musyawarah. Partisipasi mengandung konten kesetaraan dimana setiap suara dalam pertemuan dinilai sebagai input warga negara, tidak melihat dari jenis kelamin. Namun di sisi lain, kendala dari perempuan yang telah hadir dalam forum adalah kapasitas pengambilan keputusan dan kontribusi perempuan dalam forum yang seharusnya lebih ditingkatkan, sehingga perempuan mampu merespon kebutuhan-kebutuhan strategis di dalam forum, dapat mewamai dan mengintervensi Musrenbangdes dalam bentuk input kebijakan.

\section{TINJAUAN PUSTAKA}

\section{A. Gender}

\section{Pengertian Gender}

Pengertian gender menunut Muhtar (2002), bahwa gender dapat diartikan sebagai jenis kelamin sosial atau konotasi masyarakat untuk menentukan peran sosial berdasarkan jenis kelamin. Sementara Fakih (2008: 8) mendefinisikan gender sebagai suatu sifat yang melekat pada kaum laki-laki maupun perempuan yang dikonstruksi secara sosial dan kultural. Istilah gender dibedakan dari istilah seks Oakley 1997 ahli Sosiologi Inggris, merupakan orang yang mula-mula memberikan pembedaan dua istilah itu (Saptari dan Halzner, 1997: 88). 
Istilah gender merujuk kepada perbedaan karakter laki-laki dan perempuan berdasarkan kontruksi sosial budaya, yang berkaitan dengan sifat, status, posisi, dan perannya dalam masyarakat. Istilah Seks menujuk kepada perbedaan jenis kelamin laki-laki dan perempuan secara biologis terutama yang berkaitan dengan prokreasi dan reproduksi. Laki-laki dicirikan dengan adanya sperma dan penis serta perempuan dicirikan dengan adanya sel telur, rahim, vagina, dan payudara. Ciri jenis kelamin secara biologis tersebut bersifat bawaan, permanen, dan tidak dapat dipertukarkan (Abdullah, 2004: 11).

\section{Peran Gender}

Peran gender adalah peran yang dilakukan perempuan dan laki-laki sesuai dengan status lingkungan, budaya dan struktur masyarakat. Peran tersebut diajarkan kepada setiap anggota masyarakat, komunitas dan kelompok sosial tertentu yang dipersiapkan sebagai peran perempuan dan laki-laki, empat jenis peran dalam gender, yaitu :

\section{a. Peran Gender}

Peran gender adalah peran yang dilakukan perempuan dan laki-laki sesuai dengan status, lingkungan, budaya dan struktur masyarakatnya. Peran tersebut diajarkan kepada setiap anggota masyarakat, komunitas dan kelompok sosial tertentu yang dipersepsikan sebagai peran perempuan dan laki-laki. Peran laki-laki dan perempuan dibedakan atas peran produktif, reproduktif dan sosial.

\section{b. Peran Produktif}

Peran Produktif menujuk kepada kegiatan yang menghasilkan barang dan pelayanan untuk konsumsi dan perdagangan (Kimia Bhasin, 2000). Semua pekerjaan di Pabrik, kantor, pertanian dan lalinya yang kategori aktivitasnya dipakai untuk menghitung Produksi Nasional Bruto suatu Negara. Meskipun perempuan dan laki-laki keduanya terlibat di dalam ranah publik lewat aktivitas produktif, namun masyarakat tetap menganggap pencari nafkah adalah laki-laki. Contoh di sebuah kantor, bila terjadi PHK maka seringkali perempuanlah yang dikorbankan karena dianggap kegiatan laki-laki yang menghasilkan uang. Bila menujuk pada definisi kerja sebagai aktivitas yang menghasilkan pendapatan baik dalam bentuk uang maupun barang maka ativitas perempuan dan laki-laki baik di sektor formal maupun informal, di luar rumah atau di dalam rumah sepanjang menghasilakan uang atau barang termasuk peran produktif. Contoh peran produktif perempuan yang dijalankan di dalam rumah misalnya usaha menjahit, catering, salon dsb. Contoh peran produktif yang dijalankan di luar numah, sebagai guru, buruh, pedagang, pengusaha.

\section{c. Peran Reproduktif}

Peran Reproduktif dapat dibagi mejadi dua jenis, yaitu biologis dan sosial. Reproduksi biologis merujuk kepada melahirkan seorang manusia baru, sebuah aktivitas yang hanya dapat dilakukan oleh perempuan. reproduksi sosial merujuk kepada semua aktivitas merawat dan mengasuh yang diperlukan untuk 
menjamin pemeliharaan dan bertahannya hidup (Kamla Bhasin, 2000). Dengan demikian, aktivitas reproduksi adalah aktivitas yangmereproduksi tenaga kerja manusia. Merawat anak, memasak, memberi makan, mencuci, membersihkan, mengasuh dan aktivitas numah tangga lainnya masuk dalam kategori ini.

d. Peran Sosial (Kemasyarakatan)

Kegiatan kemasyarakatan merujuk kepada semua aktivitas yang diperlukan untuk menjalankan dan mengorganisasikan kehidupan masyarakat. Peran kemasyarakatan yang dijalankan perempuan adalah melakukan aktivitas yang digunakan bersama, misalnya pelayanan kesehatan di Posyandu, partisispasi dalam kegiatan-kegiatan sosial dan kebudayaan (kerja bakti, gotong royong, pembuatan jalan kampung, dll). Semua kegiatan tersebut biasanya dialakukan secara sukarelawan. Sedangkan peran sosial yang dilakukan lakilaki biasanya pada tingkatan masyarakat yang diorganisasikan, misalnya menjadi RT, RW, Kepala Desa (Masdudi, 2013: 29-30).

\section{Ketidakadilan dan Keadilan Gender}

\section{a. Ketidakadilan Gender}

Perbedaan gender antara laki-laki dan perempuan dengan pembedaan peran dan posisi sebagaimana realita yang ada pada dunia dewasa ini tidak akan menjadi masalah selama itu adil. Namun dalam kenyataan yang adaperbedaan peran tersebut membatasi gerak keduanya sehingga melahirkan ketidakadilan.
Terlebih kepada perempuan, dimana dalam realita yang ada penulis banyak sekali menyaksikan kejadian-kejadian yang merujuk pada ketidakadilan terhadap perempuan yang mana seorang anak perempuan di asumsikan tidak perlu sekolah tinggi, tidak perlu pendidikan lanjut karena pada ujungnya hanya berkutat pada pekerjaan domestik saja.

Ketidakadilan gender terutama dialami perempuan. sebagai gambaran laki-laki diakui dan dikukuhkan untuk menguasai perempuan. Kemudian hubungan perempuan dan laki-laki yang hirarkis, dianggap sudah benar dan diterima sebagai hal yang normal. Ketidakadilan gender tersebut terdapat dalam berbagai wilayah kehidupan, yaitu dalam wilayah negara, masyarakat, organisasi atau tempat kerja, keluarga dan diri sendiri ( Mumiaty, 2000 : $31)$.

Bentuk-bentuk ketidak adilan gender yaitu:

\section{Subordinasi}

Artinya suatu penilaian atau anggapan bahwa peran yang dilakukan oleh satu jenis kelamin lebih utama atau lebih penting dari yang lain. Dengan kata lain sebuah posisi atau peran yang merendahkan nilai peran yang lain. Salah satu jenis kelamin dianggap lebih penting, utama, dan tinggi dibandingkan jenis kelamin lainnya. Misalnya, lakilaki sebagai pemimpin. 


\section{Marjinalisasi (Peminggiran)}

Artinya suatu proses peminggiran atau menggeserkan kepinggiran, teliti maka anak perempuan diarahkan sekolah guru, perawat, sekretaris. Ironis pekerjaan-pekerjaan tersebut dinilai lebih rendah dibandingkan dengan pekerjaan lain yang bersifat maskulin.

\section{Beban Ganda}

Artinya beban pekerjaan yang diterima salah satu jenis kelamin lebih banyak dibandingkan jenis kelamin lainnya. Masuknya perempuan disektor publik tidak senantiasa diiringi dengan berkurangnya beban mereka didalam rumah tangga. Peran ganda yang tetap harus dijalankan baik didomain publik maupun domestik. Akibat dari perbedaan sifat dan peran, maka semua pekerjaan domestik dibebankan kepada perempuan, tuntutan ekonomi keluarga selain mengerjakan pekerjaan rumah tangga, perempuan juga harus bekerja di kebun, ke pasar mencari nafkah bagi keluarga. Perempuan masuk ke dunia politik akan tetapi beban domestiknya tidak berkurang. Akibatnya perempuan memiliki beban kerja ganda, bahkan sering dituduh mengabaikan tanggung jawab didalam numah tangga dan juga tidak berprestasi di dunia publik. Ketidakadilan nampak ketika sekalipun curahan tenaga kerja dan waktu cukup panjang temyata dihargai rendah dibandingkan pekerjaan publik.

\section{Stereotipe}

Artinya pemberian lebel atau cap yang dikenakan kepada seseorang atau kelompok yang didasarkan pada suatu anggapan yang salah atau sesat. Pelabelan atau pandangan terhadap suatu kelompok/seks tertentu yang sering kali bersifat negatif dan secara umum melahirkan ketidakadilan. Pelabelan juga menunjukan adanya relasi kekuasaan yang timpang atau tidak seimbang yang bertujuan untuk menaklukan atau menguasai pihak lain. Pelabelan yang sering dijumpai adalah pelabelan negatif yang ditujukan kepada perempuan. Misalnya, perempuan suka berdandan, dianggap untuk menarik perhatian laki-laki. Dengan demikian cocok diberi tugas sebagai penerima tamu. Perempuan sebagai pendamping suami sehingga tidak perlu dipromosi menjadi ketua atau kepala, sebab dianggap bukan pencari nafkah utama yang akan menopang ekonomi keluarga. Perempuan dianggap cengeng suka menggoda, sehingga tidak dapat dipercayakan menduduki jabatan penting/strategis.

\section{Kekerasan}

Artinya bentuk perilaku baik verbal maupun non verbal yang dilakukan seseorang atau sekelompok orang sehingga menyebabkan efek negatif secara fisik, emosional dan psikologis terhadap orang yang menjadi 
sasarannya. Indikasi bahwa perempuan mengalami kekerasan dapat dilihat dari contoh pemukulan terhadap istri, pelecehan seksual, eksploitasi seks terhadap perempuan masih tetap tinggi baik didalam maupun luar rumah (Masdudi: 33)

\section{b. Keadilan Gender}

Keadilan gender termuat dalam Lampiran Inpres No.9 Tahun 2000, menyatakan keadilan gender adalah suatu proses untuk menjadi adil terhadap laki-laki dan perempuan. Gender ini dimaksudkan untuk mengatasi ketidakadilan gender yang terjadi yang meliputi Marginalisasi, subordinasi, stereotip, kekerasan, dan beban kerja. Manifestasi ketidakadilan gendertersebut masing-masing tidak bisa dipisah-pisahkan, saling terkait dan berpenganuh secara dialektik.

Diantara gambaran dan indikasi adanya upaya untuk mewujudkan keadilan gender adalah:

1. Menerima dan memandang secara wajar perbedaaan pada laki-laki dan perempuan, karena adanya penghormatan pada perbedaan termasuk wujud dari ketidakadilan gender.

2. Mendiskusikan bagaimana cara merombak struktur masyarakat yang membedakan peran dan relasi antara laki-laki dan perempuan, serta berupa menyeimbangkannya.

3. Meneliti kemamapuan dan bakat masingmasing warga negara, baik laki-laki maupun perempuan, untuk terlibat dalam pembangungan masyarakat, memecahkan problem-problemnya dan memepersiapkan masa depannya.

4. Memperjuangkan secara terus menerus hak asasi manusia, dimana gender merupakan salah satu dari bagiannya yang tak terpisahkan.

5. Mengupayakan perkembangan dan penegakan demokrasi dan pemerintahan yang baik dalam semua institusi msyarakat, dengan melibatkana perempuan dalam semua levelnya.

6. Pendididkan merupakan kunci bagi keadilan gender, karena pendidikan merupakan tempat masyarakat mentransfer norma-norma, pengentahuan, dan kemampuan mereka.

\section{Konsep Kesetaraan Gender}

Kesetaraan berasal dari kata setara atau sederajat. Jadi, kesetaraan juga dapat disebut kesederajatan. Menurut Kamus Besar Bahasa Indonesia (KBBI), sederajat artinya sama tingkatan (kedudukan, pangkat). Dengan demikian, kesetaraan atau kesederajatan menunjukkan adanya tingkatan yang sama, kedudukan yang sama, tidak lebih tinggi atau tidak lebih rendah antara satu sama lain.

Kesetaraan manusia bermakna bahwa manusia sebagai mahkluk Tuhan memiliki tingkat atau kedudukan yang sama. Tingkatan atau kedudukan yang sama itu bersumber dari pandangan bahwa semua manusia tanpa dibedakan adalah diciptakan dengan kedudukan yang sama, yaitu sebagai makhluk mulia dan tinggi derajatnya dibanding makhluk lain. Dihadapan Tuhan, semua manusia adalah sama derajat, 
kedudukan, atau tingkatannya yang membedakan nantinya adalah tingkat ketakwaan manusia tersebut terhadap Tuhan.

Persamaan atau tingkatan manusia ini berimplikasi pada adanya pengakuan akan kesetaraan atau kesederajatan manusia. Jadi, kesetaraan atau kesederajatan tidak sekedar bermakna adanya persamaan kedudukan manusia. Kesederajatan adalah suatu sikap mengakui adanya persamaan derajat, persamaan hak dan persamaan kewajiban sebagai sesama manusia. Implikasi selanjutnya adalah perlunya jaminan akan hak-hak itu agar setiap manusia bisa merealisasikanserta perlunya merumuskan sejumlah kewajibankewajiban agar semua bisa melaksanakan agar terciptatertibkehidupan.

Kesetararaan gender di masyarakat dewasa ini mulai banyak diperbincangkan diberbagai kalangan terutama di dunia pendidikan, ekonomi, dan hukum. Dengan semakin majunya pemikiran masyarakat maka mereka yang menganggap dirinya belum mendapatkan kedudukan yang sama dan semestinya sedang berjuang untuk mendapatkan kedudukan yang sama. Hal ini bukan berarti bahwa perempuan dan laki-laki harus sama, tetapi hak, tanggung jawab dan kesempatannya tidak dipengaruhi oleh apakah mereka dilahirkan sebagai laki-laki atau perempuan.

Kesetaraan gender yang termuat dalam Lampiran Inpres No 9 Tahun 2000, yaitu Kesetaraan Gender adalah kesamaan kondisi bagi laki-laki dan perempuan untuk memperoleh kesempatan dan hak-haknya sebagai manusia, agar mampu berperan dan berpartisipasi dalam kegiatan politik, ekonomi, sosial, budaya, pertahanan, dan keamanan nasional dan kesamaan dalam menikmati hasil pembangunan tersebut.

Persamaan atau tingkatan manusia ini berimplikasi pada adanya pengakuan akan kesetaraan atau kesederajatan manusia. Jadi, kesetaraan atau kesederajatan tidak sekedar bermakna adanya persamaan kedudukan manusia. Kesederajatan adalah suatu sikap mengakui adanya persamaan derajat, persamaan hak dan persamaan kewajiban sebagai sesama manusia. Implikasi selanjutnya adalah perlunya jaminan akan hak-hak itu agar setiap manusia bisa merealisasikan serta perlunya merumuskan sejumlah kewajibankewajiban agar semua bisa melaksanakan agar tercipta tertibkehidupan.

Berkaitan dengan dua konsep di atas, maka dalam keragaman diperlukan adanya kesetaraan atau kesederajatan. Artinya, meskipun individu maupun masyarakat adalah beragam dan berbedabeda, tetapi mereka memiliki dan diakui akan kedudukan, hak-hak dan kewajiban yang sama sebagai sesama baik dalam kehidupan pribadi maupun kemasyarakatan. Terlebih lagi dalam kehidupan berbangsa dan bemegara, jaminan atau kedudukan, hak dan kewajiban yang sama dari berbagai ragam masyarakat di dalamnya amat diperlukan.

Berbeda halnya dengan keadilan gender, keadilan gender merupakan keadilan pendistribusian manfaat dan tanggung jawab perempuan dan laki-laki. Konsep yang mengenali adanya perbedaan kebutuhan dan kekuasaan antara perempuan dan laki-laki, yang harus diidentifikasi dan diatasi dengan cara memperbaiki 
ketidakseimbangan antara jenis kelamin. Masalah gender muncul bila ditemukan perbedaan hak, peran dan tanggung jawab karena adanya nilainilai sosial budaya yang tidak menguntungkan salah satu jenis kelamin (lazimnya perempuan).

\section{B. Peranan Perempuan Dalam Pembangu- nan Desa}

\section{Pengertian Peranan}

Peranan (role) merupakan aspek yang dinamis dari kedudukan (status). Artinya seseorang telah menjalankan hak-hak dan kewajibankewajibannya sesuai dengan kedudukannya, maka orang tersebut telah melaksanakan sesuatu peran. Keduanya tak dapat dipisahkan karena satu dengan yang lain saling tergantung, artinya tidak ada peran tanpa status dan tidak ada status tanpa peran. Sebagaimana kedudukan, maka setiap orang pun dapat mempunyai macam-macam peran yang berasal dari pola pergaulan hidupnya. Hal tersebut berarti pula bahwa peran tersebut menentukan apa yang diperbuatnya bagi masyarakat serta kesempatan- kesempatan apa yang diberikan masyarakat kepadanya. Peran sangat penting karena dapat mengatur perilaku seseorang, di samping itu peran menyebabkan seseorang dapat meramalkan perbuatan orang lain pada batas-batas tertentu, sehingga seseorang dapat menyesuaikan perilakunya sendiri dengan parilaku orang-orang sekelompoknya (Narwoko, 2004:138).

Peran yang melekat pada diri seseorang harus dibedakan dengan posisi atau tempat dalam pergaulan kemasyarakatan. Posisi atau tempat seseorang dalam masyarakat (socialposition) merupakan unsur statis yang menunjukkan tempat individu dalam organisasi masyarakat. Sedangkan peran lebih banyak menunjuk pada fungsi, artinya seseorang menduduki suatu posisi tertentu dalam masyarakat dan menjalankan suatu peran. Suatu peran paling sedikit mencakup 3 hal, yaitu:

1. Peran meliputi norma-norma yang dihubungkan dengan posisi atau tempat seseorang dalam masyarakat;

2. Peran adalah suatu konsep ikhwal apa yang dapat dilakukan oleh individu dalam masyarakat; dan

3. Peran dapat dikatakan sebagai perilaku individu yang penting bagi struktur sosial masyarakat.

Peranan sosial yang ada dalam masyarakat dapat diklarifikasikan menurut bermacam-macam cara sesuai dengan banyaknya sudut pandang. Berbagai macam peranan dapat disebutkan sebagai berikut (Narwoko, 2004:140).Berdasarkan pelaksanaannya peranan sosial dapat dibedakan menjadi dua, yaitu:

1. Peranan yang diharapkan (expected roles): cara ideal dalam pelaksanaan peranan menurut penilaian masyarakat. Masyarakat menghendaki peranan yang diharapkan dilaksanakan secermat- cermatnya dan peranan ini tidak dapat ditawar dan harus dilaksanakan seperti yang ditentukan.

2. Peranan yang disesuaikan (actual roles), yaitu cara bagaimana sebenamya peranan itu dijalankan. Peranan ini pelaksanaannya lebih luwes, dapat disesuaikan dengan situasi dan kondisi tertentu. Peranan yang disesuaikan mungkin tidak cocok dengan situasi setempat, 
tetapi kekurangan yang muncul dapat dianggap wajar oleh masyarakat.

Sementara itu, berdasarkan cara memperolehnya, peranan bisa dibedakan menjadi:

1. Peranan bawaan (ascribed roles), yaitu peranan yang diperoleh secara otomatis, bukan karena usaha, misalnya peranan sebagai nenek, anak, kepala desa dan sebagainya; dan

2. Peranan pilihan (achives roles), yaitu peranan yang diperoleh atas dasar keputusannnya sendiri, misalnya seseorang yang memutuskan untuk menjadi kepala desa.

\section{Pembangunan Desa}

Pembangunan adalah segala upaya untuk mewujudkan perubahan sosial besar-besaran dari suatu keadaan kehidupan nasional menuju keadaan baru yang lebih baik. Perubahan sosial tersebut meliputi berbagai aspek kehidupan dan berlangsung secara terus menerus.Dalam kebijakan pembangunan nasional di negara Indonesia, pembangunan desa merupakan bagian integral dari pembangunan nasional. Maka pembangunan desa oleh Mubyarto (1988:10) didefinisikan sebagai pembangunan yang berlangsung di pedesan dan meliputi seluruh aspek kehidupan masyarakat yang dilaksanakan secara terpadu dengan mengembangkan swadaya gotong royong.

Salah satu faktor pembentuk kemampuan untuk untuk mewujudkan masa depan yang direncanakan menurut Bryant \& White (1987:24) adalah empowerment. Dengan empowerment masyarakat mempunyai kesempatan untuk terus mengembangkan kemampuan dan peranannya dalam merencanakan dan melaksanakan sendiri perubahan-perubahan yang mereka kehendaki untuk mewujudkan masa depan yang lebih baik.

Pembangunan yang terkait dengan empowerment adalah pembangunan desa, yang bertujuan untuk meningkatkan kemampuan masyarakat dan lembaga desa secara simultan. Dengan tujuan itu pembangunan desa dirancang untuk menjadi landasan yang kokoh bagi pembangunan daerah dan pembangunan nasional, selain itu pembangunan desa juga diharapkan dapat menjadi pembangunan yang berwawasan masa depan dan berkelanjutan.

\section{Peran Perempuan Dalam Pembangunan}

Di Indonesia pembahasan dan penyelesaian tentang wanita atau perempuan sama pentingnya dengan pembahasan dan penyelesaian di segala bidang. perempuan hanya dianggap sebagai subyek yang pekerjaannya sebagai konsumen penghabis gaji atau pendapatan yang diperoleh suami. Anggapan seperti tidak dapat dibenarkan, karena disadari perempuan jugaberkemampuan untuk mencari nafkah atau gaji untuk mendapatkan alternatif pendapatan dan berprestasi.

Berdasarkan uraian di atas, pengertian dari peran ganda perempuan dalam pembangunan adalah kegiatan, tugas, ataupun partisipasi perempuan yang mencakup sektor domestik maupun sektor publik pada masa sekarang yang dikenal dengan masa pembangunan.

Perempuan sebagai pemegang peranan penting bahkan utama dalam bidang politik bukanlah hal baru dalam sejarah kehidupan bangsa ini. Sebagaimana telah diketahui bahwa perempuan telah menjadi aktor penting dalam perjuangan kaum nasionalis dalam lingkungan 
publik yang menandai masuknya bangsa ini ke era modemitas. Dapat dikatakan bahwa pra modemitas senantiasa diiringi dengan adanya proses pembangunan. Pengertian proses pembangunan adalah perubahan sosial budaya yang akan meliputi pula perubahan nilai. Wanita di samping sebagai istri, ibu diharapkan aktif dalam organisasi dimana suami bekerja, karena status istri sebagai pendamping suami dan menunut informasi turut menentukan kondisi suami. Untuk dapat berpartisipasi dengan baik dalam masyarakat, pendidikan merupakan syarat yang mutlak (Soedarsono dan Murmiatmo 1986:60).

Pergeseran dan peran (pembagian kerja) antara laki-laki dan perempuan dalam keluarga dan rumah tangga, terjadi ketika seorang ibu mempunyai peran yang sangat penting di dalam masyarakat dan Negara. Di mana peran wanita tidak hanya untuk dipimpin tetapi juga untuk memimpin. Hal itu harus mendapatkan pengakuan yang positif dan pasti.

Pembagian peran privat dan publik tidak relevan jika diterapkan dalam masyarakat Jawa, karena dalam masyarakat Jawa wanita sudah terbiasa dengan peran privat sekaligus publik. Hal ini terutama terjadi pada masyarakat Jawa golongan petani dan pedagang, dimana wanita mengurus rumah tangga (domestic) sekaligus mencari nafkah (ekonomi- publik). Pola pembagian privat dan publik sesungguhnya telah dipatahkan oleh ideologi produksi yang menganut paham fungsionalisme struktural. Paham ini mengatakan bahwa pembagian privat-publik berlawanan dengan ideologi produksi. Menurut ideologi produksi, wanita juga berproduksi.
Dalam Sociological Theory atau dalam penjabaran teori sosiologi, Parsons mengatakan bahwa walaupun pengukuran yang dipakai untuk menilai status wanita dan laki- laki berbeda, namun status wanita sama dengan status laki-laki. Pola perkawinan menurut Parsons, merupakan hubungan antara dua orang yang sederajat (Saptari dan Holsner 1997:64-67). Dalam arti bahwa status perempuan diperoleh atas dasar status suami istri, dan dapat pula diperoleh atas dasar posisi pekerjaannya.

Mosse (1996:30-31) mengungkapkan bahwa dalam setiap masyarakat, antara laki-laki dan perempuan memiliki peran gender yangberbeda. Ada perbedaan yang mereka lakukan dalam komunitasnya sehingga status maupun kekuasaan mereka dalam masyarakat menjadi berbeda. Akan menarik jika ditemukan kedudukan suami istri dalamposisi seimbang. Gejala matrifokalitaspada masyarakat Jawa terlihat dengan adanya pandangan kesetaraan antara lakilaki dan perempuan dalam sistem peran sosial secara umum. Bahkan kedudukan dan peran seorang ibu dianggap penting dalam masyarakat Jawa karena kaum ibu tidak hanya mengasuh dan mendidik anak serta mendampingi suami, tetapi juga diperkenalkan untuk keluar rumah melakukan kegiatan ekonomi.

Pada dasarnya peran serta perempuan sangat diperlukan untuk melestarikan kebudayaan yang sangat berguna bagi generasi selanjutnya. Perempuan tidak hanya perlu ditingkatkan pengetahuan, kemampuan, dan ketrampilannya, tetapi perempuan harus mempunyai kebesaran jiwa dan keluhuran budi. Demi keberhasilan 
pembangunan diperlukan peran serta dari perempuan, oleh karenanya dorongan, bantuan moril, dan pengertian dari kaum laki-laki dari suami khususnya sangat diperlukan.

\section{METODE PENELITIAN}

Jenis penelitian ini adalah penelitian deskriptif dengan pendekatan kualitatif. Disebut demikian karena jenis penelitian ini memberikan penekanan (fokus) pada upaya mendeskripsikan keadaan sebagaimana adanya (Irawan 2004:60), dimana tujuannya adalah menghasilkan data deskriptif berupa kata-kata tertulis atau lisan dari orang-orang atau perilaku yang dapat diamati (Bagdon dan Taylor dalam Moleong, 2001:3) yang dimaksudkan untuk eksplorasi dan klasifikasi mengenai suatu fenomena atau kenyataan sosial.

\section{PEMBAHASAN}

Perempuan menjadi penting untuk dibahas secara khusus dalam pelaksanaan Undang-Undang Desa. Setidaknya ada tiga alasan. Pertama, perempuan sebagai individu dan kelompok selama ini mengalami diskriminasi dan peminggiran dalam berbagai kebijakan dan program pembangunan, dan juga dalam kehidupan sosial. Di berbagai tempat, diskriminasi dan peminggiran ini bahkan masih berlangsung sampai sekarang.

Kedua, Undang-Undang Desa secara khusus menyebut perempuan sebagai unsur masyarakat yang harus diikutsertakan dalam Musyawarah Desa (Musdes). Kita sudah tahu bahwa Musdes merupakan forum tertinggi dalam pengambilan keputusan menyangkut hal-hal strategis di desa. Undang-undang Desa, dengan demikian, mengakui hak perempuan untuk berpartisipasi dalam pengambilan keputusan penting menyangkut desa dan kehidupan masyarakatnya. Ini berarti, keberadaan UndangUndang Desa ditujukan salah satunya untuk mengoreksi problem ketimpangan atau ketidakadilangender dalam pelaksanaan proses pembangunan yang selama ini kurang mendapat perhatian.

Problem ketimpangan gender ini tampak salah satunya dari laporan pencapaian tujuan pembangunan milenium (MDGs), di mana Indonesia gagal dalam mengatasi persoalan tingginya angka Kematian lbu dan Anak (KIA). Maraknya kasus kekerasan terhadap perempuan juga mencerminkan adanya ketimpangan gender dalam masyarakat.

Ketiga, Undang-Undang Desa menegaskan prinsip kesetaraan dan keadilan gender dalam pengaturan desa dan dalam pelaksanaan pemerintahan desa. Ini berarti undangundang desa memberikan perhatian khusus dan menekankan pentingnya tindakan afirmatif bagi perempuan. Melakukan tindakan afirmatif bagi perempuan dapat memberikan efek ganda, yaitu peningkatan kualitas/kapasitas perempuan dan sekaligus peningkatan kualitas pembangunan desa. Dengan melibatkan perempuan dalam pengambilan keputusan yang berdampak terhadap kehidupan diri dan kelompoknya, maka pembangunan desa akan lebih efektif mengatasi persoalan kemiskinan, ketimpangan, dan keterbelakangan. Sebab persoalan kemiskinan, ketimpangan, dan keterbelakangan lebih banyak dihadapi dan diderita oleh perempuan. Itulah 
mengapa Undang-Undang Desa memasukkan perempuan sebagai salah satu unsur masyarakat yang harus terlibat dalam Musdes.

Melaksanakan Undang-Undang Desa berarti mengawal dan mewujudkan pemenuhan hak-hak warga dan komunitas - terutama hak-hak mereka yang miskin, marjinal dan rentan. Perempuan adalah salah satunya. Dalam hal ini pelaksanaan Undang-Undang Desa diarahkan untuk memperkuat keadilan dan kesetaraan gender melalui berbagai tindakan afi masi bagi kelompok perempuan. Tindakan afi masi ini, misalnya, memastikan alokasi khusus bagi kelompok perempuan dalam musyawarah desa, baik dalam hal keterwakilan proporsi/jumlah maupun keterwakilan kepentingan terkait program dan anggaran pembangunan.

Prinsip kesetaran dan keadilan gender yang ada dalam undang-undang desa dijalankan oleh desa-desa. Selain itu pembahasan ini juga ditujukan agar hal-hal berikut dapat dicapai :

1. Mempromosikan partisipasi aktif dan setara antara perempuan dan laki-laki dalam proses pengambilan keputusan di masyarakat, mulai dari tingkat komunitas terkecil (keluarga) maupun di ranah publik termasuk di tingkat desa

2. Memastikan perempuan dan laki-laki sebagai subjek memiliki akses, kontrol, dan manfaat yang sama atas sumber daya yang ada

3. Memastikan setiap desa memiliki perspektif dan langkah-langkah strategis dalam memahami dan mengatasi persoalan ketidakadilan gender yangda di masing-masing desa serta memiliki pemahaman dalam mengintegrasikan gender dalam selunuh proses pembangunan desa

4. Mendorong berbagai pihak di desa memahami pentingnya melakukan analisis gender untuk menjawab persoalan ketidakadilan gender yang terjadi di level desa.

\section{A. Keterlibatan Perempuan Dalam}

\section{Kelembagaan Pembangunan Desa}

Lingkungan keluarga memiliki pengaruh yang cukup besar bagi perempuan untuk berpartisipasi dalam kegiatan di ranah publik. Dorongan dari anggota keluarga seperti suami dan anak-anak untuk melakukan kegiatan sosial dengan terlibat sebagai anggota kelembagaan desa. Meskipun demikian menurut penuturan kaum perempuan yang terjun di ranah publik dan terlibat dalam kepengurusan lembaga desa, harus pandaipandai membagi waktu, jangan sampai kepentingan keluarga terabaikan karenanya. Selain dukungan lingkungan keluarga, dukungan dari lingkungan luar pada umumnya juga sebagai faktor pendukung peran perempuan dalam kelembagaan desa.

Dalam perencanaan pembangunan desa partisipasi kaum perempuan dapat di lihat dari keaktifan kaum perempuan yang memberikan kontribusi pemikiran sehingga berjalannya pelaksanaan progam pembangunan dengan tepat dan menghadiri rapat atau apapun itu yang berkaitan dalam pembangunan.

Menurut Sumardi (2010:46), 'Partisipasi berarti peran serta seseorang atau kelompok masyarakat dalam proses pembangunan baik dalam bentuk pemyataan maupun dalam bentuk kegiatan dengan member masukan pikiran, tenaga, 
waktu, keahlian, modal dan atau materi, serta ikutmemanfaatkan dan menikmati hasil-hasil pembangunan.

\section{B. Partisipasi Perempuan Dalam}

\section{Pembangunan Desa}

Partisipasi perempuan dalam pembangunan sangat ditunjang melalui beberapa indikator penting yang menjadi barometer dalam menentukan tingkat partisipasi perempuan dalam meningkatkan pembangunan daerah.

Perkembangan peran perempuan dan posisi kaum perempuan sejak masa lampau hingga saat ini telah menempatkan perempuan sebagai mitra sejajar dengan kaum pria. Perempuan memiliki kesempatan dan mempunyai tanggung jawab yang sama terhadap kehidupan bermasyarakat, berbangsa dan bemegara demi majunya pembangunan.

Penelaan kerja perempuan tidak terlepas dari sosialisasi peran perempuan yang sangat kompleks. Di samping berperan sebagai isteri, sebagai ibu, sebagai pengatur rumah tangga, sebagai tenaga kerja perempuan, juga berperan sebagai anggota masyarakat dan manusia pembangunan.

Salah satu peran perempuan dalam pembangunan adalah dengan ikut berperan dalam menciptakan program-program yang mengarah kepada pemberdayaan perempuan dengan meluncurkan program diversifikasi pangan dan gizi yaitu program yang berupaya mengintensifikasi pekarangan sebagai salah satu gerakan ketahanan pangan keluarga dan masyarakat melalui pemanfaatan lahan pekarangan. Dengan melihat peran tersebut para perempuan memiliki kemandirian yang kuat.

Adapun sosok perempuan yang diharapkan saat ini adalah yang mampu membuat dan menciptkan keluarga progresif dan militant dalam arti penuh daya juang melalui:

a. Memperkokoh kehidupan beragama dan beriman terutama lewat pendidikan.

b. Meningkatkan profesionalisme dengan jalan terus menerus belajar, menambah pengatahun, pengalaman, dan kemahiran teknis dan manajamen sosial.

c. Menyusun strategi organisasional moderen dengan jalan membentuk organisasi perempuan yang kokoh, solid, terintegrasi untuk memperjuangkan hak-hak wanita dalam persamaan untuk berkembang dan maju dalam segalabidang.

Ada banyak hal yang bisa diupayakan untuk meningkatkan kualitas sumber daya manusia atau perempuan sehingga berperan secara aktif dalam pembangunan antara lain:

1. Sosialisasi secara berkesinambungan,

2. Membangun kesepakatan pembangunan,

3. Pemberdayaan perempuan antar pemerintah dan swasta, serta masyarakat itu sendiri agar mewujudkan kesetaraan jender di segala bidang,

4. Meningkatkan akses informasi yang dapat diterima oleh kaum perempuan di segala hal, khususnya informasi pembangunan serta melibatkan dalam pengambilan keputusan. (Hayunieta,2007 :2)

Peran perempuan dalam pembangunan tidak hanya terbatas bagi kaum perempuan yang 
tinggal di perkotaan namun saat ini peran perempuan yang tinggal di pedesaan pun telah ikut andil dalam menentukan arah pembangunan bagi desanya. Walaupun masih terdapat beberapa kendala dalam keiikut sertaan perempuan dalam suatu lembaga desa yang ada di desanya, terutama menyangkut masalah kesetaraan gender antara kaum lai-laki dan perempuan. Peran perempuan terhadap pembangunan masih menjadi hal yang dianggap kurang penting oleh masyarakat, sehingga seringkali terjadi ketidakadilan gender terhadap peran perempuan untuk ikut melaksanakan pembangunan di berbagai bidang.

Untuk mewujudkan terlaksananya kesetaraan gender dan peran serta perempuan dalam pembangunan desa, maka pemerintah harus mengawal implementasi Undang-Undang Nomor 6 Tahun 2014 tentang Desa secara sistematis, konsisten dan berkelanjutan. Paradigma UndangUndang Desa mendudukan desa tidak hanya sebagai unit administraif di bawah pemerintahan daerah tetapi telah memberikan kewenangan yang begitu besar untuk mengunus urusan masyarakatnya (self goverming community).Sehingga dengan demikian desa memiliki kewenangan dan dapat melaksanakan Undang-Undang Desa untuk memenuhi hak-hak warga desa. Peluang untuk menciptakan kesejahte- raan, keadilan, dan mengatur desa dengan cara sendiri, telah diberikan oleh UndangUndang Desa.

Ada banyak sekali peran yang bisa diambil dan dimainkan oleh perempuan desa dalam rangka pelaksanaan pembangunan desa. Dilihat dari kewenangan desa yang telah diatur dalam
Permendesa No. 1 tahun 2015 di sana diatur apa saja kewenangan yang dimiliki desa sebagai dasar dan kuasa untuk melaksanakan pembangunan dan meningkatkan kesejahteraan warga desa. Perempuan bisa mengambil banyak sekali peran pembangunan di sana, lebih jauh dan lebih dalam lagi dari PKK, dasawisma, posyandu, PAUD desa dan raskin.

Kewenangan kewenangan desa hampir semua membuka peluang bagi perempuan untuk memerankannya. Tidak ada keharusan bahwa kewenangan desa harus dijabat dan dilakukan oleh laki laki. Bahwa ada banyak kendala dan tantangan untuk menuju ke sana maka hal itulah yang perlu di jawab oleh perempuan desa itu sendiri dan pemerintah desa. Tingkat keterlibatan perempuan dalam pembangunan desa dari tahun ke tahun perlu terus dipantau dan didorong peningkatannya.

Perempuan desa perlu bersegera untuk menyiapkan kemampuan diri mengisi porsi dalam melaksanakan wewenang desa berdasarkan hak asal usul. Misalnya dengan menjadi perangkat Desa; terlibat dalam sistem organisasi masyarakat adat; melibatkan diri dalam pembinaan kelembagaan masyarakat; atau turut dalam pembinaan lembaga dan hukum adat.

\section{Beberapa Pendekatan Perempuan dalam Pembangunan}

Ada beberapa pendekatan yang dapat digunakan untuk mengetahui peran dan partisipasi perempuan dalam pembangunan, yaitu:

\section{Pendekatan Kesejahteraan (Welfare Approach)}

Pendekatan ini didasarkan atas tiga asumsi yaitu: 
a. perempuan sebagai penerima pasif pembangunan,

b. peran keibuan yang merupakan peranan yang paling penting bagi perempuan dalam masyarakat, dan

c. mengasuh anak yang merupakan peranan perempuan yang paling efektif dalam semua aspek pembangunan ekonomi (Ratna Saptari, 1998: 158)

Pendekatan tersebut seluruhnya dititikberatkan pada peran reproduktif perempuan dan menempatkan perempuan di arena pribadi, sementara laki-laki dipandang sebagai kelompok masyarakat yang aktif dalam arena publik.

Oleh karena itu, proyek-proyek untuk kesejahteraan ini menitikberatkan pada pemenuhan kebutuhan fisik keluarga melalui penyediaan perumahan, sandang, pangan, dan melalui proyekproyek latihan mengenai tata laksana rumah tangga, tentang makanan bergizi serta cara menyiapkan sebagai upaya pencegahan kekurangan gizi dan lain-lain.

Namun, kalau dilihat secara normatif kedudukan perempuan dengan pria adalah sejajar, akan tetapi dalam kehidupan nyata seringkali terendah dengan apa yang lazim disebut dengan istilah gender stratification yang menempatkan status perempuan dalam tatanan hirarkis pada posisi subordinal atau tidak persis sejajar dengan posisi kaum pria (Sunyoto Usman, 2004: 114)

Dari pemyataan diatas temyata dalam beberapa hal wanita dan pria dalam kegiatan ekonomi mempunyai persamaan terutama dalam proses transformasi ekonomi yang mereka bagi tiga kategori periode perkembangan antara lain:।
1. The family-based economy, pada periode ini wanita sebenamya tidak hanya bekerja dalam urusan rumahtangga, melainkan juga terlibat dalam kegiatan diluar rumah, terutama di bidang pertanian. Bahkan di beberapa tempat dimana kota sudah mulai berkembang, wanita berpartisipasi juga dalam kegiatan jasa dan perdagangan. Kegiatan ekonomi wanita dan pria memamg agak berbeda, namun tetap ada semacam ketergantungan satu sama lain. Oleh karena itu tidak terlalu berlebihan apabila dikatakan bahwa status dan peran perempuan lebih kurang sejajar dengan status dan peran yang dimiliki oleh pria.

2. The family-wage economy, ditandai dengan transformasi kegiatan ekonomi dari pertanian keperdagangan, sejajar dengan perkembangan kapitalisme, sehingga dalam periode ini tenaga kerja tidak lagi terkonsentrasi pada kegiatan rumah tangga tetapi di luar rumah terutama di pabrik yang tumbuh dan berkembang bersamaan dengan proses industrialisasi dan perkembangan teknologi.

3. The family-consumer economy, dalam perode ini terjadi perubahan teknologi yang cukup pesat dan peningkatan produktivitas yang dalam perkembangannya membuat anggota rumah tangga lebih banyak melakukan fungsi konsumsi. Dan hal ini terjadi karena wanita mempunyai fungsi ganda .Dalam kondisi demikian produktivitas wanita bahkan dapat lebih tinggi dari pada periode sebelumnya. Itulah sebabnya wanita hanya dianggap sebagai penerima meskipun dalam beberapa kasus juga diketemukan bahwa penghasilan yang mereka 
peroleh masih sangat diperlukan dalam memberi dukungan pada pemenuhan kebutuhan keluarga.

Dengan memahami uraian diatas memperihatkan bahwa industrialisasi telah mengubah pola atau pengaturan kesempatan kerja. Perkembangan industri yang melaju dengan pesat disamping menciptakan kelas pekerja (working class) dalam jumlah yang sangat besar, juga banyak menciptkan banyak kelas menengah (middle class) Karl Marx dalam (Sunyuto Usman, 2004: 119 ). Dan ketika produksi dan dunia perdagangan maju dengan pesat, manajemen juga berkembang semakin kompleks, antara lain ditandai dengan meningkatnya pekerjaan yang berkaitan dengan administrasi dengan akuntansi. Meskipun demikian kesempatan kerja bagi wanita untuk bekerja pada bidang semacam ini masih terbatas dibanding dengan kaum pria.

\section{Pendekatan kesamaan (Equity Approach)}

Pendekatan ini mengakui bahwa perempuan merupakan partisipan aktif dalam proses pembangunan yang mempunyai sumbangan terhadap pertumbuhan ekonomi melalui kerja produktif dan reproduktif mereka, walaupun sumbangan tersebut seringkali tidak diakui.

Dengan mengakui sumbangan ekonomi perempuan, pendekatan ini melawan ketaksejajaran perempuan terhadap lelaki. Program-program yang berdasarkan pendekatan ini langsung diarahkan pada hak-hak yuridis perempuan termasuk hak untuk cerai, hak atas anak, hak milik harta, dan hak untuk mendapatkan kredit dan hak sebagai warga negara.
Namun, pada akhimya konsekuensinya kemudian adalah semakin terbatasnya kesempatan dan akses wanita dalam urusan-unusan yang berkaitan dengan aktivitas publik (publik sphere). Kalaupun perempuan terlibat dalam publik pada umumnya menempati bidang-bidang yang hanya bersentuhan dengan domestik, dan itulah sebabnya dalam percaturan politik perempuan berada dipinggir. Kemudian usaha peningkatan jumlah dan kualitas elit politik perempuan sebagaian besar tergantung pada kemauan politik dari kelas yang berkuasa. Maka dari itu tidak mengherankan apabila sebagian orang kemudian merasa tidak ada gunaya mempersoalkan kelangkaan elit politik perempuan, karena dikalangan kaum pria sendiri masalah keadilan politik juga masih memprihatinkan.

\section{Pendekatan Anti Kemiskinan (Anti-poverty Approach)}

Pendekatan anti kemiskinan ini merupakan bentuk lebih halus dari pendekatan kesamaan karena lembaga-lembaga pembangunan enggan untuk mencampuri ketimpangan hubungan jender. Pendekatan ini lebih menekankan pada upaya menurunkan ketimpangan pendapatan antara perempuan dan pria. Kelompok sasarannya adalah para pekerja yang miskin. Pendekatan ini sejalan dengan strategi pembangunan "pemerataan dengan pertumbuhan" (redistribution with growth) dan strategi "kebutuhan dasar" "(basic needs).

Pendekatan anti kemiskinan ini untuk perempuan menitikberatkan pada peranan produktif mereka, atas dasar bahwa penghapusan kemiskinan dan peningkatan keseimbangan pertumbuhan ekonomi membutuhkan 
peningkatan produktivitas perempuan pada rumah tangga yang berpendapat rendah. Pendekatan ini berdasarkan asumsi bahwa asal mula kemiskinan perempuan dan ketimpangannya dengan lelaki diakibatkan oleh kesenjangan peluang untuk memiliki tanah dan modal serta diskriminasi seksual dalam pasar tenaga kerja. Dan dalam perancangan proyek ini menciptakan penghasilan bagi perempuan diutamakan seolah-olah usahausaha skala kecil mempunyai kemampuan untuk tumbuh secara mandiri.

Melihat kenyataan tersebut di atas tentang berbagai hal yang dapat menimbulkan kemiskinan ada beberapa cara untuk menanggulangi permasalahan tersebut antara lain:

1. Mengurangi jumlah penduduk yang hidup dalam kemiskinan

2. Melaksanakan delapan jalur pemerataan yang meliputi pemerataan pembagian pendapatan, penyebaran pembangunan di seluruh daerah, kesempatan memperoleh pendidikan, kesehatan, kesempatan kerja, berusaha, berpartisipasi dalam kegiatan pembangunan dan kesempatan memperoleh keadilan.

Semua hal tersebut disepakati kembali bahwa program-program pembangunan yang dilaksanakan tidak hanya mengejar kemajuan lahiriah melainkan juga memenuhi kepuasaan batiniah. Bahkan pada saat itu juga hasil-hasil pembangunan hendaknya merata keselunuh penjuru bukan hanya kepada sebagaian orang (Sunyoto Usman, 2004:130).

\section{Pendekatan efisiensi (Efficiency Approach)}

Dalam pendekatan ini telah bergeser dari perempuan kepembangunan dengan asumsi bahwa peningkatan partisipasi ekonomi perempuan dengara dunia ketiga secara otomatis berkaitan dengan peningkatan kesamaan. Perubahan ini khususnya terjadi di Amerika Latin dan Afrika, dimana masalah-masalah resesi ekonomi diakibatkan jatuhnya harga barang ekspor, proteksionisme, beban utang. Dan Secara praktis perubahan-perubahan tersebut menyebabkan meningkatnya kerja perempuan yang tidak diupah dan perempuan sendiri yang menciptkan pekerjaan diluar sektor informal. Dan pada waktu yang bersamaan ideologi tentang perempuan sebagai ibu dan ibu rumah tangga makin diperkuat.

\section{Pendekatan pemberdayaan (Empowerment Approach)}

Pendekatan ini lahir dari ketidakpuasaan terhadap pendekatan-pendekatan sebelumnya. Mereka berasumsi bahwa untuk memperbaiki posisi perempuan dalam pembangunan ada beberapa intervensi yang tidak disertai dengan upaya untuk meningkatkan kekuasaan perempuan dalam melaksanakan negosiasi, tawar menawar dan untuk mengubah sendiri siatuasinya, tidak akan berhasil. Pendekatan ini berpusat pada upaya penghapusan subordinasi perempuan. Pendekatan ini tidak terlalu menyibukkan diri dalam proyekproyek pembangunan, tetapi menemukan perwujudannya dalam beberapa kegiatan gerakan perempuan di dunia ketiga.

Satu hal yang perlu digarisbawahi ketika kita berbicara mengenai upaya penanggulangan kemiskinan adalah pemberdayaan perempuan, karena mereka memiliki andil yang kuat dalam 
terciptanya kemiskinan masyarakat. Hal ini terjadi karena peran perempuan dalam keluarga sangat menentukan arah dan tujuan kehidupan keluarga itu sendiri.

Peran serta perempuan dalam pembangunan dan penyetaraan gender, khususnya dalam mengimplememtasikan Undang-Undang Desa merupakan salah satu perwujudan hak-hak masyarakat desa dalam memajukan desa mereka dengan mengikutsertakan kaum perempuan dalam pembangunan desa. Sehingga yang diharapkan adalah penyetaraan gender bagi kaum perempuan di desa dalam ikut serta pembangunan desa bisa terlaksana dengan baik dengan memberikan ruang dan peluang bagi kaum perempuan untuk berkontribusi dalam pembangunan desa.

\section{PENUTUP}

Indonesia telah melangkah pada tonggak sejarah baru, salah satuya ditandai dengan lahirnya Undang Undang No.6 Tahun 2014 tentang Desa. Kebijakan ini mengandung cara pandang baru yang menegaskan bahwa desa bukan sekadar wilayah administratif semata. Namun desa merupakan "negara kecil" yang mempunyai wilayah, kekuasaan, pemerintahan, institusi lokal, penduduk, tanah, dan sumberdaya ekonomi. Cara pandang baru ini memberi harapan dan peluang terhadap visi pembahanuan desa menuju perubahan yang jauh lebih besar dan lebih baik daripada sebelumnya

Begitu pula bagi perempuan, dimana kebijakan ini dapat menjadi momentum bagi perempuan di desa untuk mengoptimalkan perannya dalam rangka mengubah posisinya dari obyek menjadi subyek pembangunan di desa.
Seperti diketahui bahwa selama ini perempuan selalu mengalami peminggiran hak-haknya dalam keseharian. Momentum ini dapat menjadi pintu masuk untuk pembenahan relasi gender dalam kehidupan sehari-hari.

\section{DAFTARPUSTAKA}

Darwin, M. Muhadjir. 2005. Negara dan Perempuan: Reorientasi KebijakanPublik. Yogyakarta: MediaWacana

Hayunieta. 2007. Perempuan dan Pembangunan: Marjinalisasi

Irawan, Handi 2004. Prinsip-prinsip Kepuasan Pelanggan. Jakarta. PT. Elex Media Komputindo

Moleong, Lexy J. 2002. Metodologi Penelitian Kualitatif. Bandung: PT. Remaja Rosdakarya.

Mosse, Julia Cleves. 1992. Gender dan Pembangunan. Yogyakarta: Pustaka Pelajar.

Mubyarto, 1989, Strategi Pembanguan Pedesaan, P3PK, UGM, Yokyakarta

Natsir. 2007. Peran Perempuan dalam Meningkatkan Pembangunan. Jakarta: Bumi Aksara

Nugroho, riant. 2008. Gender Dan Administrasi Publik. Yogyakarta: Pustaka Belajar

Nurhalimah, Andi. 2018. Patisipasi Perempuan Dalam Perencanaan Pengelolaan Dana Desa. Jumal Imu Administrasi Negara. Vol. 6 No. 2. ISSN 23545798

Pusat Kajian Wanita dan Gender, Universitas Indonesia, 2007.“Hak Azazi Perempuan Instrument Hokum Untuk Mewrujudkan KeadilanGender",Jakarta: Yayasan Obor Indonesia

Ratna, Megawangi. 1999. Membiarkan Berbeda: Sudut Pandang Baru Tentang Relasi Gender. Bandung: Mizan

Rostyaningsih,2010. Konsep Gender. Semarang : LPPMUNDIP 
Volume 2 Nomor 2 Edisi Maret 2020

Saptari, Ratna.1997.Perempuan Kerja dan Perubahan Sosial. Jakarta: Pustaka Utama Grafiti.

Siagian, SP, 1983. Administrasi Pembangunan.Gunung Agung

Soekanto Soerjono. 2006. Sosiologi Suatu Pengantar. Jakarta: Raja Grapindo Persada.

Sugiono, 2012. Metodelogi Penelitian Kuantitatif, Kualitatif Dan $R \& D . \quad$ Bandung: Alfabeta
Usman Sunyoto. 2004. Pembangunan dan Pemberdayaan Masyarakat. Yogyakarta: Pustaka Pelajar

Sumber Undang-Undang:

Permendagi no 114 tahun 2014 Tentang Pedoman Pembangunan Desa

UUNO6 Tahun 2014 Tentang Desa 